\title{
The Muscidae (Diptera) from the Atlantic Forest of Serra de Paranapiacaba, southestern Brazil
}

\author{
Silvio Shigueo Nihei ${ }^{1,3}$; Anderson Tatsuki Tamakoshi ${ }^{1,4}$; Priscylla Moll ${ }^{1,5}$ \& Rodrigo Ferreira Krüger ${ }^{2,6}$ \\ 1 Universidade de São Paulo (USP), Instituto de Biociências (IB-USP), Departamento de Zoologia. São Paulo, SP, Brasil. \\ ${ }^{2}$ Universidade Federal de Pelotas (UFPEL), Instituto de Biologia (IB), Departamento de Microbiologia e Parasitologia (DEMP). Pelotas, RS, Brasil. \\ ${ }^{3}$ ORCID: http://orcid.org/0000-0002-6887-6282. E-mail: silvionihei@gmail.com \\ ${ }^{4}$ ORCID: http://orcid.org/0000-0003-3954-1018. E-mail: anderson.tamakoshi@gmail.com \\ ${ }^{5}$ ORCID: http://orcid.org/0000-0002-0226-7732. E-mail:pmoll.bio@gmail.com \\ ${ }^{6}$ ORCID: http://orcid.org/0000-0003-1040-8299. E-mail: rfkruger@gmail.com
}

\begin{abstract}
A first survey of Muscidae in the State of São Paulo (Southeastern Brazil) is presented here with a one-year of Malaise trap collecting from August 2010 to July 2011 at the Biological Reserve Alto da Serra de Paranapiacaba $\left(23^{\circ} 46^{\prime} 00^{\prime \prime}-23^{\circ} 47^{\prime} 10^{\prime \prime} \mathrm{S}\right.$, $46^{\circ} 18^{\prime} 20^{\prime \prime}-46^{\circ} 20^{\prime} 40^{\prime \prime} \mathrm{W}, 750-891 \mathrm{~m}$ of altitude). A total of 1,284 individuals of muscids were collected, and 15 genera and 39 species of Muscidae were identified. So far, only one muscid species had been recorded to the Reserve, which now has its Muscidae diversity increased to 40 species. Thirteen species are new records for the State of São Paulo. With this, the number of species of Muscidae species known to occur in the State of São Paulo is increased to 169. The interval between November and February was higher in number of individuals and number of species. Muscidae presented a seasonal pattern, with more abundance and diversity in that interval. The study area is covered by secondary forest and very close to São Paulo metropolitan area, and the composition of the fauna of Muscidae signalizes this environment changing and anthropic stress with nine species with synanthropic habits, two of them are typically synanthropic species.
\end{abstract}

Keywords. Diversity; Inventory; Neotropical region; Seasonality; State of São Paulo; Survey.

\section{INTRODUCTION}

The family Muscidae is worldwide distributed and include about 5,200 described species in 187 genera (Pape et al., 2011). In the Neotropical Region there are over 800 species and 85 genera (Couri \& Carvalho, 2005). The family is greatly abundant in all continents, occurring in most oceanic islands, and also in the Arctic and regions of tundra vegetation (Huckett \& Vockeroth, 1987). Muscid flies have diverse feeding habits, including predators, phytophagous, saprophagous, anthophilous, parasites and haematophagous (Couri, 1999; Savage \& Vockeroth, 2010; Carvalho et al., 2012).

There are a number of studies with inventory of Diptera in the Neotropics (e.g., Carvalho \& Couri, 1991; Couri et al., 2000; Pamplona et al., 2000; Krüger et al., 2010; Borkent et al., 2018; Zafalon-Silva et al., 2018), on the other hand, several studies focused on groups with agricultural or forensic importance (e.g., Ferraz et al., 2009; Mulieri et al., 2011; Garcia et al., 2003; Cavallari et al., 2015; Carvalho et al., 2017; Olea et al., 2017). With regard to Muscidae, there are a number of inventories in Brazil, but unbalanced between the different Brazilian biomes and states. For example, while there is a voluminous literature on Muscidae for the States of Paraná and Rio de Janeiro (e.g., Carvalho et al., 1984; D'Almeida, 1991; Pamplona et al., 2000; Oliveira et al., 2002; Costacurta et al., 2003; Couri \& Carvalho, 2005; Leandro \& D'Almeida, 2005; Rodríguez-Fernández et al., 2006; Couri \& Barros, 2009), the most rich and populous Brazilian State remains with the Muscidae diversity knowledge still incipient. Furthermore, it is relatively scarce the Muscidae surveys in the Neotropics based on the use of non-baited collecting techniques (e.g., Carvalho \& Couri, 1991; Costacurta et al., 2003; RodríguezFernández et al., 2006; Krüger et al., 2010; ZafalonSilva et al., 2018). The present study is the first exhaustive survey of Muscidae for the State of São Paulo based on non-baited collectings. Previous surveys focused on urban and/or cadaveric fauna (Linhares, 1981; Dias et al., 2014; Cavallari et al., 2015). In Brazil, 358 species are described and recorded, 156 of these occur in the State of São Paulo (Lowenberg-Neto \& Carvalho, 2013, with updates from Pereira-Colavite \& Carvalho, 2012; Cavallari et al., 2015; Fogaça \& Carvalho, 2018). In this article we surveyed the Muscidae of the 
Biological Reserve Alto da Serra de Paranapiacaba (State of São Paulo, southeastern Brazil) in the Atlantic Forest biome, and analyzed its abundance, diversity and seasonality throughout a one-year collecting period. So far, only one muscid species had been recorded to the Biological Reserve of Paranapiacaba (Townsend, 1927; Lowenberg-Neto \& Carvalho, 2013).

\section{MATERIAL AND METHODS}

\section{Study area and collection}

This survey took place in the Biological Reserve Alto da Serra de Paranapiacaba (Fig. 1) (2346 $00^{\prime \prime}, 23^{\circ} 47^{\prime} 10^{\prime \prime} \mathrm{S}$; $46^{\circ} 18^{\prime} 20^{\prime \prime}, 46^{\circ} 20^{\prime} 40^{\prime \prime} \mathrm{W}, 750-891 \mathrm{~m}$ of altitude), located

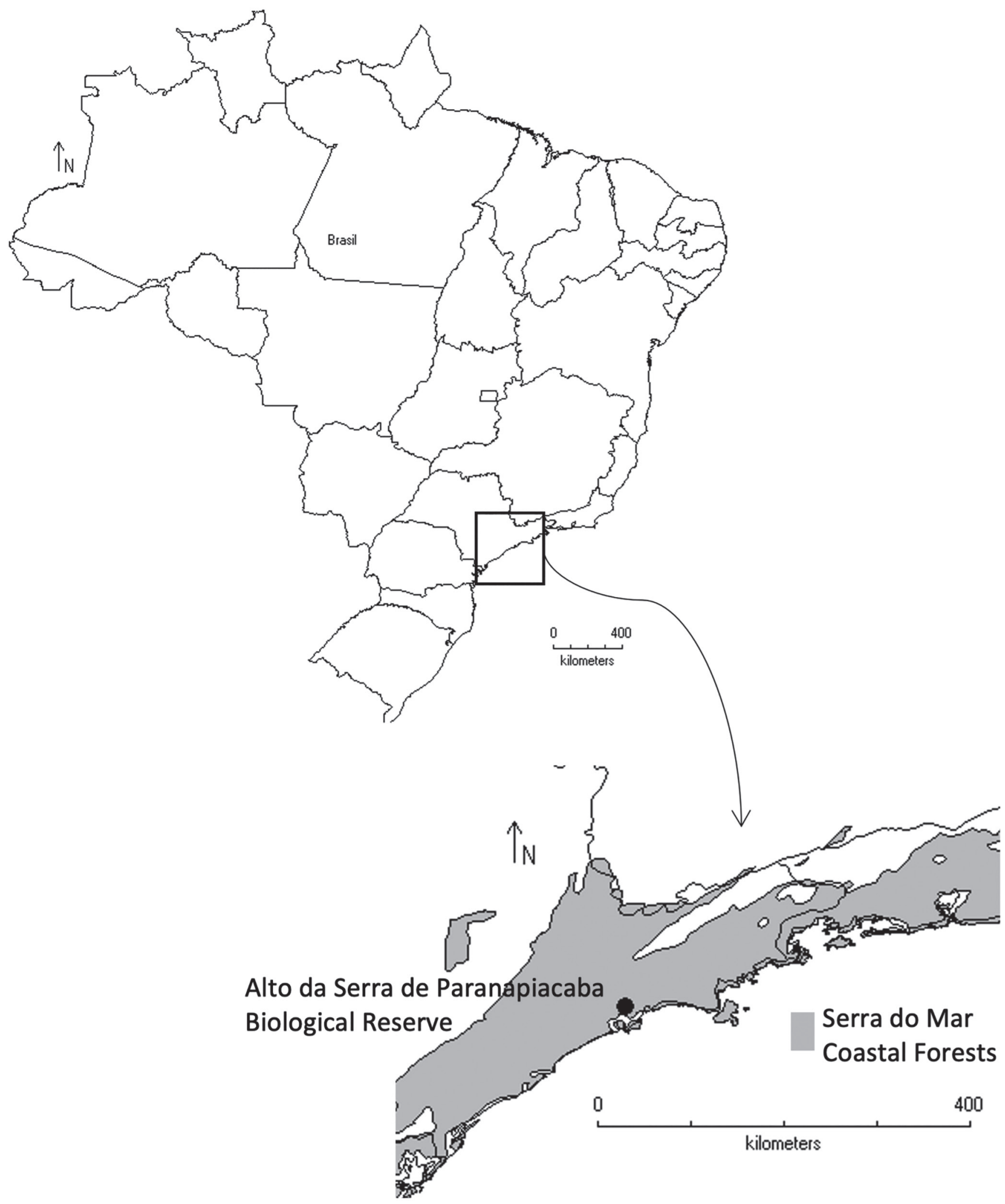

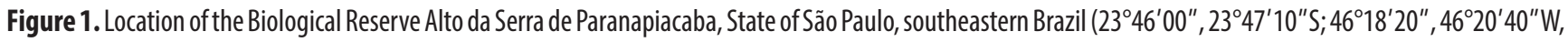
750-891 m of altitude). 
in the municipality of Santo André, State of São Paulo, Brazil. The reserve is situated slightly under the Capricorn Tropic $\left(23^{\circ} 27^{\prime} S\right)$, in a transition area between the Tropical and the Subtropical climates zones (Gutjahr \& Tavares, 2009). According to Köppen's classification, the climate type is Cwa, temperate and humid, with dry winter and hot summer. The mean temperature at summer (December-March) is $20^{\circ} \mathrm{C}$, and $14^{\circ} \mathrm{C}$ on winter (JuneSeptember), with temperature range of $6^{\circ} \mathrm{C}$ (Gutjahr \& Tavares, 2009). The area is predominantly covered with secondary Atlantic Forest under different successional stages, and that altered flora is due to historical anthropic intervention (Sugiyama et al., 2009), as this area is very close to São Paulo metropolitan area.

Insects were collected using Malaise traps, installed at three different point of the Reserve: trap 1 was located at $23^{\circ} 46^{\prime} 38^{\prime \prime} \mathrm{S}, 46^{\circ} 18^{\prime} 42,7^{\prime \prime} \mathrm{W}$; trap 2 at $23^{\circ} 46^{\prime} 44.6^{\prime \prime} \mathrm{S}$, $46^{\circ} 18^{\prime} 40,2^{\prime \prime} \mathrm{W}$; and trap 3 at $23^{\circ} 46^{\prime} 45,7^{\prime \prime} \mathrm{S}, 46^{\circ} 18^{\prime} 29,2^{\prime \prime} \mathrm{W}$. Traps were installed and material had been collected continuously from August 2010 to July 2011. Sampling vessels were replaced monthly, and the collected material taken to the lab for sorting and identification.

\section{Identification}

The specimens were recognized until the genera and species level, using identification keys in Carvalho (2002). When necessary, taxonomic revisions were consulted, containing updated identification keys and descriptions (e.g., Pereira-Colavite \& Carvalho, 2012; Nihei \& Carvalho, 2007; among others). All studied material was pinned and, in most cases, males and/or females were dissected to study their terminalia, which were compared to drawings and descriptions in the literature. The dissected terminalia were cleared with $10 \% \mathrm{KOH}$ solution, then neutralized with acetic acid solution and washed with water; after examination, they were stored in microvials with glycerine and pinned with the respective specimen. The material was deposited at the Museu de Zoologia, Universidade de São Paulo, São Paulo (MZSP).

\section{Data analyses}

Quantitative data were analyzed by calculating Shannon diversity and Berger-Parker dominance indexes (Magurran, 1988) to compare the diversity and proportional abundance of species among the four stations of the year. These calculations were performed in the software DivEs v2.0 (Rodrigues, 2005). To analyze the seasonality abundance in the four seasons of the year, we conducted the Kruskal-Wallis statistical test for non-parametric samples using the software Past version 2.17c (Hammer et al., 2001). We have applied a Kruskal-Wallis post-test called Bonferroni Correction, used to reduce the chances of obtaining false-positive results (type I errors) when several pairwise tests are made for one dataset (Nakagawa, 2004).

The estimation of the number of species and extrapolation of this variable and their respective confidence in- tervals (95\%) as a function of abundance was performed in R using the statistical package iNEXT (Hsieh et al., 2016) based on the methodologies proposed by Colwell et al. (2012) and Chao et al. (2014).

Collector curves were obtained for the Biological Reserve Alto da Serra de Paranapiacaba and for each seasonal season within the same area.

\section{RESULTS}

Within the one-year of Malaise trap collected material, seven families of Calyptrata were surveyed: Calliphoridae, Fanniidae, Mesembrinellidae, Muscidae, Rhinophoridae, Sarcophagidae and Tachinidae. Those seven families accounted a total of 3,451 individuals, with Muscidae as the most abundant, with 1,284 individuals (37\%). Excluding the genera formerly belonging to "Coenosiinae" (sensu Carvalho et al., 2005), the collected material of Muscidae was restricted to 397 individuals, and a total of 15 genera and 39 species of Muscidae were identified (Table 1 and Appendix) from the three subfamilies of Muscidae: Muscinae, Cyrtoneurininae and Mydaeinae (following the subfamilial classification sensu Haseyama et al., 2015). Thirteen species are new records for the State of São Paulo: Dolichophaonia machadoi (Albuquerque, 1958), D. simplex (Albuquerque, 1958), Helina discreta (Wulp, 1896), H. gigantea Albuquerque, 1956, H. regobarrosi Albuquerque, 1958, Neomuscina anajeensis Pereira-Colavite \& Carvalho, 2012, N. transporta Snyder, 1949, Neurotrixa sulina Costacurta \& Carvalho, 2005, Phaonia advena Snyder, 1957, P. annulata (Albuquerque, 1957), P. grandis (Couri, 1982), P. lentiginosa Snyder, 1957 and Polietina minor (Albuquerque, 1956). With this, the number of species of Muscidae known to occur in the State of São Paulo is increased to 169.

Quantitative data analysis reveals that the interval between November and February had both more individuals (Fig. 2) and more species (Fig. 3) collected. Those three-month period have a sequence of 60-55-56 individuals, while other months reached up to 36 individuals. For species number, we had a variation of 14 to 18 species. Shannon diversity index confirms summer with the highest diversity, followed by spring, autumn and winter (Table 2). On the other hand, Berger-Parker dominance shows summer with the lowest rate, followed by spring and autumn, and with winter with the highest rate. In Berger-Parker dominance, the lower the index the higher the dominance of such taxon (Table 2).

The estimated values of Chao for the richness of muscid species in the Biological Reserve was 65.009 \pm 12.198. The Chao estimator is accurate in its lower limit and based on it, we can infer that about 52 species are expected in the area, seven more than the observed richness. This value can reach 105 species, which is an overestimate due to the 14 singletons (species with only one individual) (31.11\%) (Table 3). There is also no trend towards stabilization of the collector curve (Fig. 4a), corroborating Chao's analysis for the Biological Reserve. 
Table 1. Species of Muscidae (excluding "Coenosiinae") from Biological Reserve Alto da Serra de Paranapiacaba with the number of individuals per season in the period August 2010 to July 2011. Asterisks indicate new records to State of São Paulo.

\begin{tabular}{|c|c|c|c|c|}
\hline Species & Winter & Spring & Summer & Autumn \\
\hline Cyrtoneurina alifusca & 1 & 1 & 6 & 1 \\
\hline Cyrtoneurina costalis & 0 & 0 & 0 & 1 \\
\hline Cyrtoneuropsis maculipennis & 7 & 11 & 41 & 18 \\
\hline Cyrtoneuropsis polystigma & 3 & 14 & 21 & 0 \\
\hline Dolichophaonia machadoi* & 5 & 6 & 3 & 1 \\
\hline Dolichophaonia simplex* & 0 & 1 & 0 & 0 \\
\hline Helina discreta* & 0 & 0 & 3 & 1 \\
\hline Helina gigantea* & 0 & 2 & 0 & 0 \\
\hline Helina praecipua & 1 & 0 & 0 & 0 \\
\hline Helina regobarrosi* & 0 & 0 & 3 & 0 \\
\hline Morellia humeralis & 0 & 0 & 1 & 0 \\
\hline Morellia nigricosta & 0 & 0 & 3 & 0 \\
\hline Mydaea plaumanni & 3 & 1 & 3 & 1 \\
\hline Myospila meditabunda & 0 & 1 & 1 & 0 \\
\hline Neomuscina anajeensis* & 0 & 1 & 0 & 0 \\
\hline Neomuscina atincticosta & 0 & 0 & 1 & 0 \\
\hline Neomuscina inflexa & 0 & 0 & 2 & 0 \\
\hline Neomuscina neosimilis & 0 & 0 & 2 & 0 \\
\hline Neomuscina schadei & 0 & 0 & 0 & 1 \\
\hline Neomuscina transporta* & 0 & 1 & 0 & 0 \\
\hline
\end{tabular}

\begin{tabular}{lcccc}
\hline \multicolumn{1}{c}{ Species } & Winter & Spring & Summer & Autumn \\
\hline Neurotrixa sulina* $^{*}$ & 0 & 0 & 1 & 0 \\
Phaonia advena* $^{*}$ & 5 & 16 & 20 & 12 \\
Phaonia annulata* $^{*}$ & 0 & 0 & 1 & 1 \\
Phaonia grajauensis $^{*}$ & 0 & 0 & 2 & 0 \\
Phaonia grandis* $^{*}$ & 29 & 25 & 32 & 25 \\
Phaonia lentiginosa* $^{*}$ & 2 & 5 & 7 & 3 \\
Phaonia shannoni $_{\text {Phaonia similata }}$ & 2 & 1 & 1 & 0 \\
Phaonia trispila $^{*}$ & 0 & 1 & 0 & 0 \\
Philornis amazonensis & 1 & 0 & 0 & 0 \\
Polietina minor* & 0 & 1 & 1 & 0 \\
Polietina prima & 0 & 0 & 1 & 0 \\
Polietina orbitalis & 0 & 0 & 3 & 3 \\
Polietina steini & 0 & 0 & 1 & 0 \\
Polietina univittata & 0 & 0 & 2 & 0 \\
Pseudoptilolepis fulvapoda & 0 & 0 & 3 & 1 \\
Pseudoptilolepis nudapleura & 1 & 6 & 4 & 1 \\
Psilochaeta pampiana & 0 & 0 & 1 & 0 \\
Synthesiomyia nudiseta & 0 & 0 & 2 & 0 \\
\hline & 0 & 0 & 0 & 1 \\
\hline
\end{tabular}

Table 2. Shannon diversity and Berger-Parker dominance indexes. The highest rates are highlighted in bold.

\begin{tabular}{lcc}
\hline & Shannon's index & Berger-Parker \\
\hline Autumn & 0,8181 & 0,3521 \\
Winter & 0,7643 & 0,5 \\
Spring & 0,9609 & 0,266 \\
Summer & $\mathbf{1 , 0 9 7 9}$ & $\mathbf{0 , 2 3 9 8}$ \\
\hline
\end{tabular}

Table 3. Muscidae richness (Chao) from August 2010 to July 2011 at the Biological Reserve Alto da Serra de Paranapiacaba (ReBio) in São Paulo, Brazil. Observed values (Obs), estimated (est), standard error of the estimated values (SE), lower (LL) and upper (UL) limits of the estimated values.

\begin{tabular}{lccccc}
\hline \multirow{2}{*}{ Local/Season } & \multicolumn{5}{c}{ Richness (Chao) } \\
\cline { 2 - 6 } & Obs & est & SE & LL & UL \\
\hline ReBio & 45 & 65.009 & 12.198 & 51.649 & 105.217 \\
Spring & 27 & 37.003 & 7.942 & 29.541 & 66.375 \\
Summer & 35 & 75.230 & 28.364 & 46.584 & 174.720 \\
Autumn & 17 & 27.507 & 10.125 & 19.146 & 68.441 \\
Winter & 16 & 19.948 & 5.228 & 16.549 & 44.380 \\
\hline
\end{tabular}

bilization in the collector curve for summer, spring and autumn, while in the winter the collections were sufficient (Fig. 4b).

The seasonality analysis using Kruskal-Wallis statistical test (Table 4) showed a seasonal pattern for the abundance of Muscidae throughout the year, with significative difference between the number of individuals distributed in the stations. The difference among the stations found at Kruskal-Wallis test was due to the abundance of individuals in the summer when compared to the winter and fall seasons. Furthermore, the circular analysis (Fig. 5) supported the seasonal variation of Muscidae indicating a clustered distribution $(r=0,913)$.

The five most abundant species (Fig. 6) were Phaonia grandis (28.17\%), Cyrtoneuropsis maculipennis Macquart, 1843 (19.54\%), Phaonia advena (13.45\%), Cyrtoneuropsis polystigma (Wulp, 1896) (9.13\%), and Phaonia lentiginosa $(4,31 \%)$.

\section{DISCUSSION}

Table 4. Pairwise Kruskal-Wallis analyses. Correction of Bonferroni are in gray color. Significative values are underlined.

\begin{tabular}{lcccc}
\hline & Winter & Spring & Summer & Autumn \\
\hline Winter & & 0,262 & $\underline{0,0005}$ & 0,629 \\
Spring & 1 & & $\underline{0,013}$ & 0,532 \\
Summer & $\underline{0,003}$ & 0,077 & & $\underline{0,0009}$ \\
Autumn & 1 & 1 & $\underline{0,006}$ & \\
\hline
\end{tabular}

Estimates of Muscidae richness for each season of the year, as well as their extrapolation, reveal interesting patterns of sampling effort for this conservation unit. In Table 3 we can see that there are higher values in the summer than in any other season, without a trend of sta-

In the Biological Reserve Alto da Serra de Paranapiacaba, only one muscid species, Philornis mima (Townsend, 1927), had been recorded so far (Townsend, 1927; Lowenberg-Neto \& Carvalho, 2013). With the 39 species found in the present survey, the Muscidae diversity of the Reserve is increased to a total of 40 species.

Malaise traps are efficient in collecting very active flying insects that can be intercepted by its tents, especially Hymenoptera and Diptera (Campos et al., 2000). In tropical rain forests of the Neotropical Region, Diptera is the most collected order when using Malaise traps (Dutra \& Marinoni, 1994; Brown, 2005). Costacurta et al. (2003) and Rodríguez-Fernández et al. (2006) analyzed the composition, species richness and abundance of Muscidae in six 
localities in Paraná State, southern Brazil in the Atlantic Forest biome, during one-year with Malaise traps. Krüger et al. (2010) surveyed four localities in southern Brazilian grasslands in the Pampa biome using a one-year Malaise traps collecting; and Zafalon-Silva et al. (2018) collected Muscidae in the 35 areas in the Coastal Plain of the Rio Grande do Sul State, southern Brazil. Borkent et al. (2018) surveyed three localities in the Costa Rican cloud forests using 13-month Malaise traps.
When considering the main surveys of Muscidae for southern Brazil (Rodríguez-Fernández et al., 2006; Krüger et al., 2010; Zafalon-Silva et al., 2018), we observe that the richness in this family, disregarding the Coenosiinae, is 109 species for Paraná State (Rodríguez-Fernández et al., 2006), 59 species for localities in the grasslands and south coast of Lagoa dos Patos (Krüger et al., 2010) and 63 species for the coastal plain of the Rio Grande do Sul (Zafalon-Silva et al., 2018), values that are 31 to

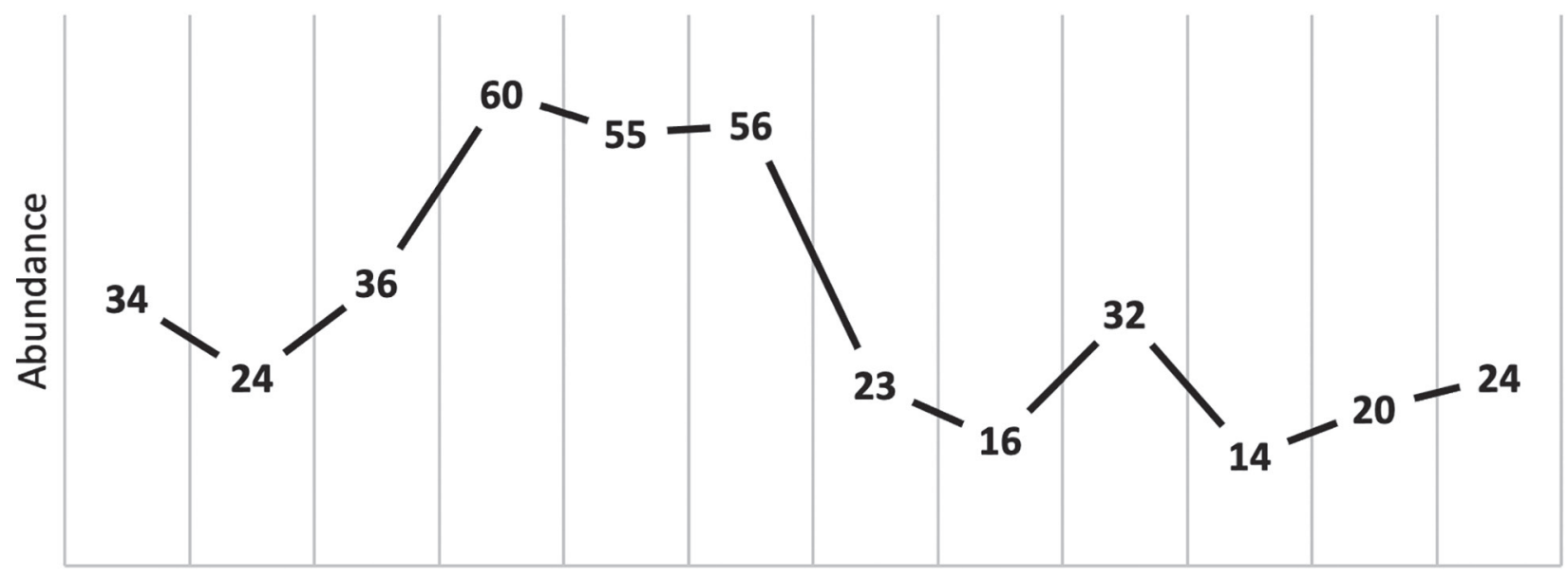

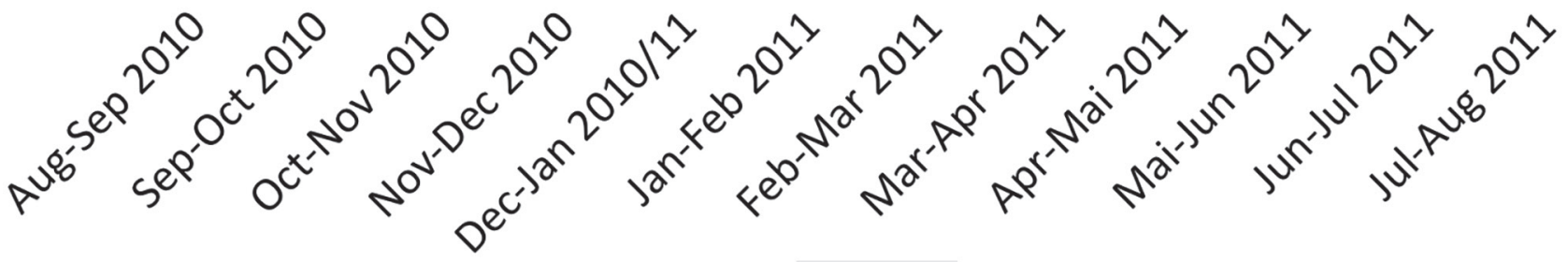

\section{Months}

Figure 2. Number of individuals of Muscidae per month for the whole year of study.

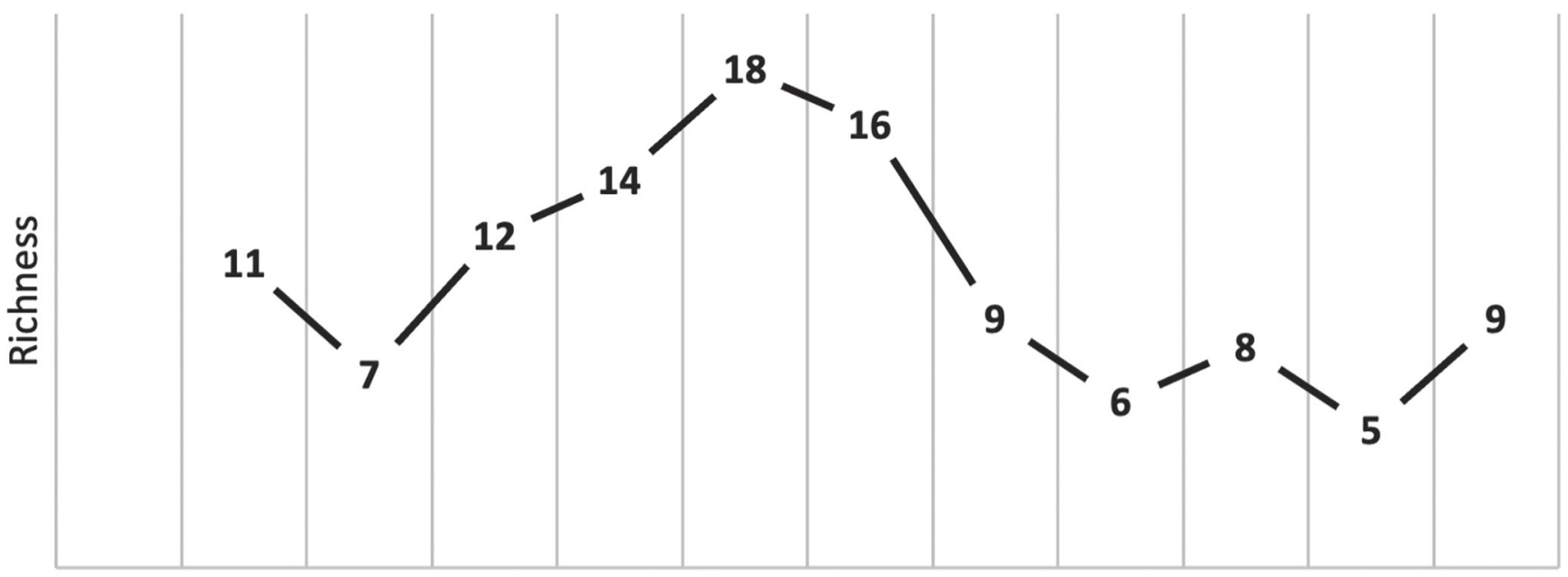

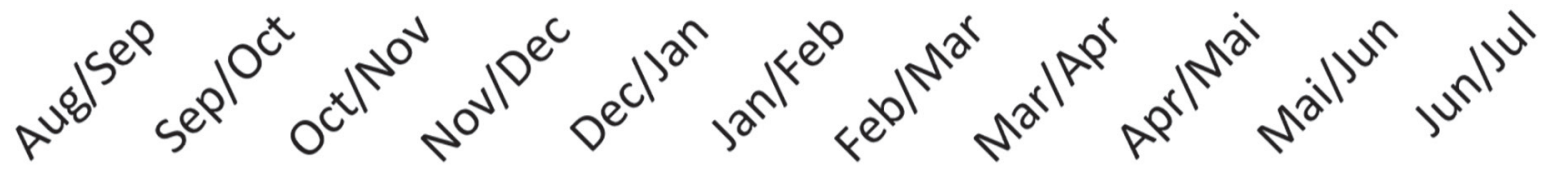

\section{Months}

Figure 3. Number of species of Muscidae per month for the whole year of study. 
$132 \%$ higher than that found for Biological Reserve of Paranapiacaba. It is worth mentioning that the morphospecies richness values are also much higher than those found here, varying from $23 \%$ of the fauna in Krüger et al. (2010) to 38\% in Rodríguez-Fernández et al. (2006), while in this work only four species were not nominally identified (8.89\%). Therefore, when disregarding mor- phospecies, the richness in the Biological Reserve of Paranapiacaba was of 41 species, values close to those found by Krüger et al. (2010) and Zafalon-Silva et al. (2018), 45 and 42 species, respectively. In Paraná, the richness was of 67 species (Rodríguez-Fernández et al., 2006), remaining 63\% higher than in Paranapiacaba. The collections carried out at the Biological Reserve of
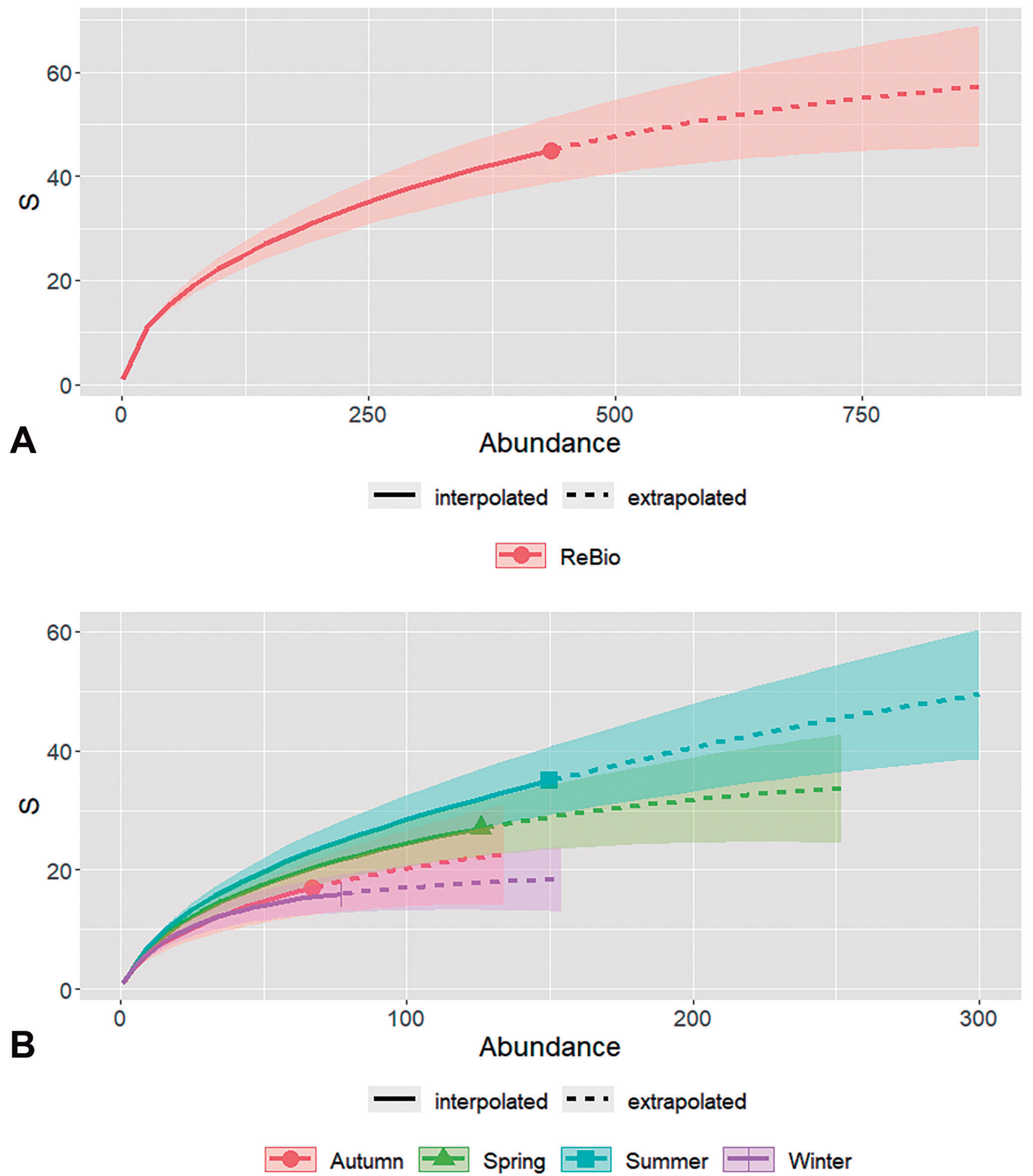

Figure 4. Species accumulation curve based on the abundance of muscids captured with Malaise traps at the Biological Reserve Alto da Serra de Paranapiacaba, State of São Paulo. The solid line represents the observed richness of the collection and the dashed line the richness estimated by Chao 1. (A) corresponds to the estimates for the Reserve considering all collections. (B) corresponds to the estimates for each season of the year: spring (green), summer (blue), autumn (purple) and winter (red). 


\section{Muscidae}

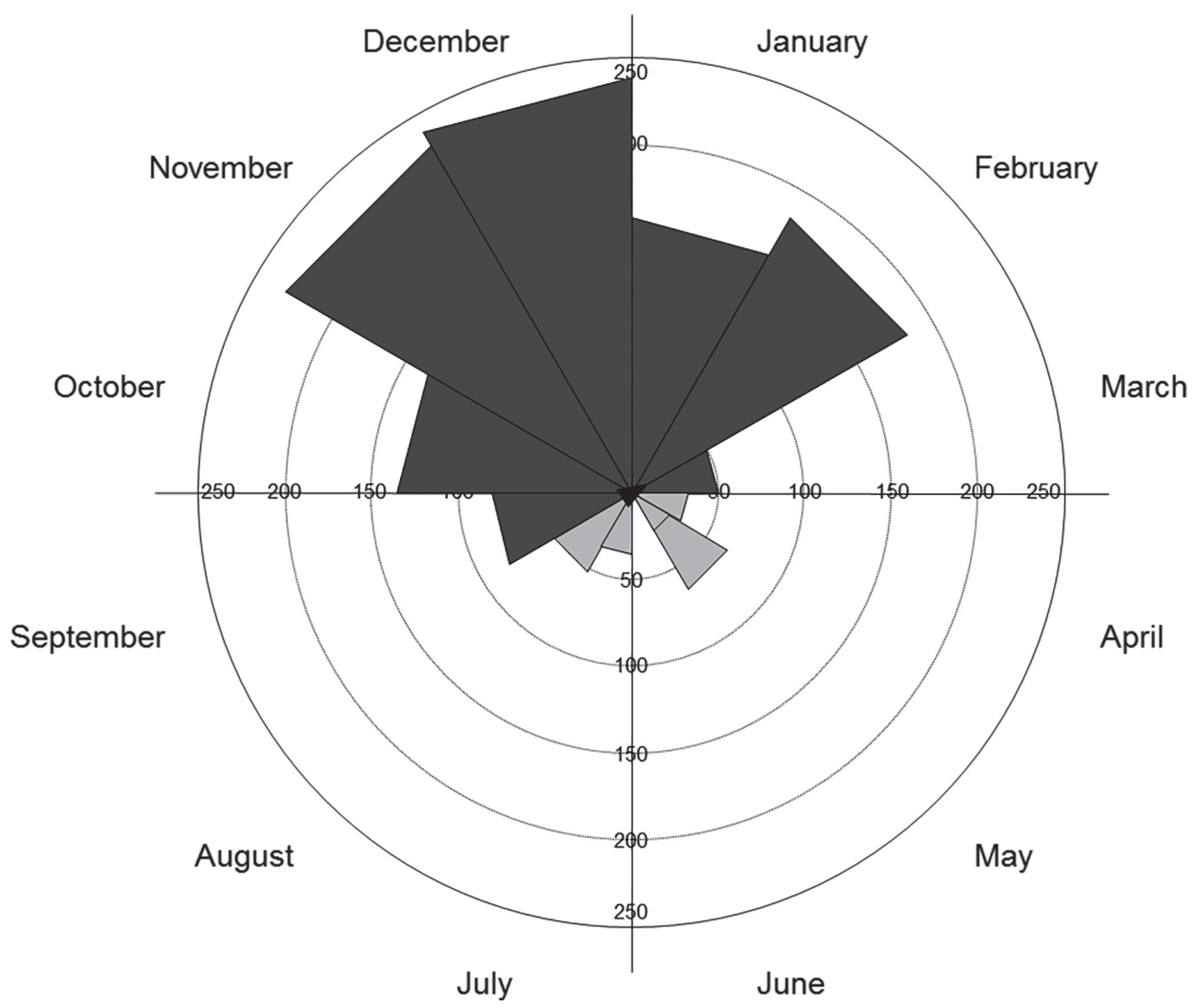

Figure 5. Circular representation of the number of collected individuals of Muscidae per month, for the whole year of study. Dark grey = rainy season; light grey = dry season. $r$ = concentration index.

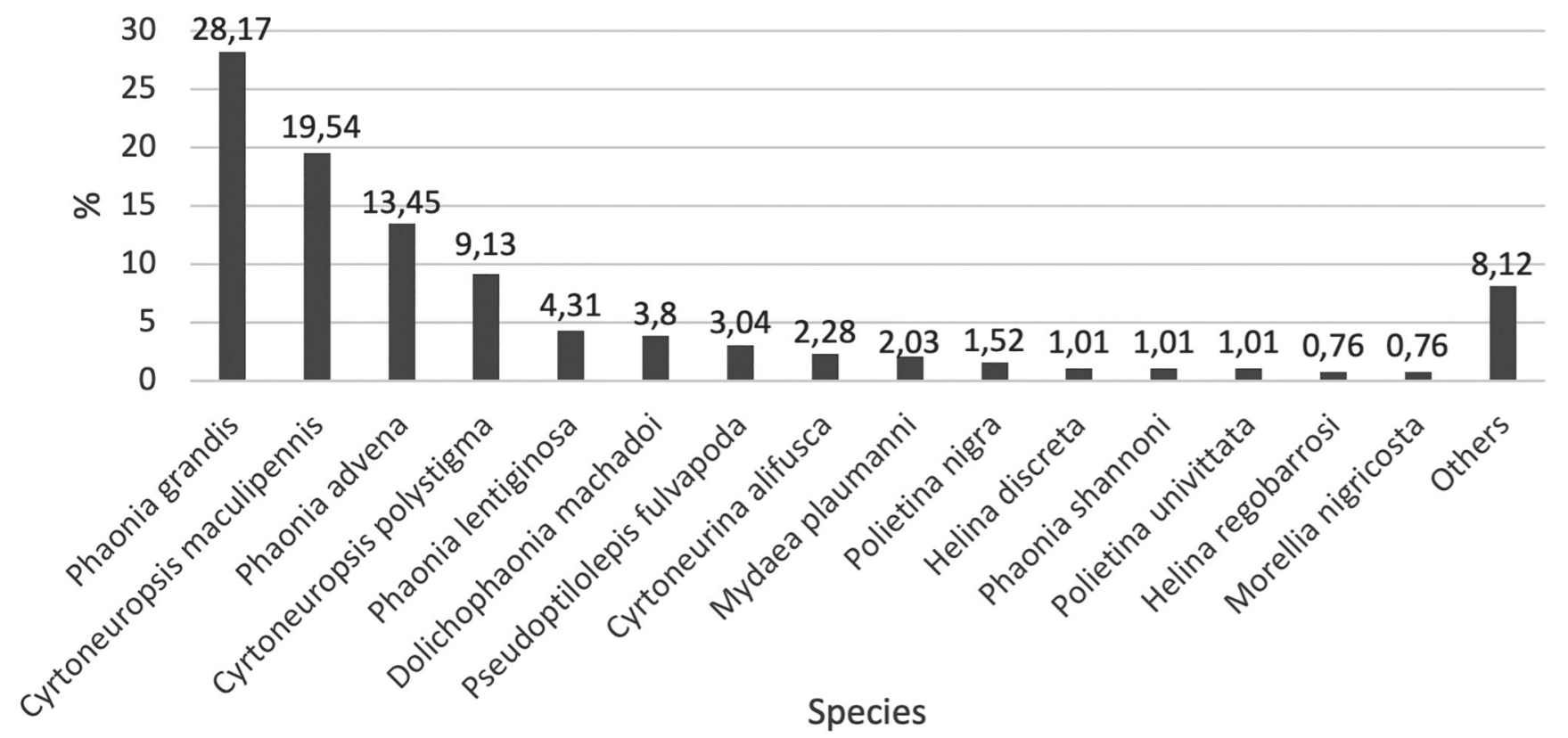

Figure 6. Relative frequency of 15 most abundant species of Muscidae sampled. The column "others" comprises 24 low abundant species. 
Paranapiacaba used traps that were placed close to each other (separated by hundreds of meters), and this may explain the much higher values in Paraná, where the collections were carried out in almost the entire State (separated by hundreds of kilometers). Nevertheless, we can estimate a great richness for Muscidae in the Atlantic Forest of São Paulo State, since in a reduced area as the Biological Reserve of Paranapiacaba, the richness found was to similar to that found in areas of much larger collections as Rio Grande do Sul, wherein sampled localities were separated by dozens of kilometers. In fact, the Chao estimate in Table 3 extrapolates more species to be collected at Paranapiacaba and, in this case, we can consider estimates higher than the estimated one. Thus, the curve of the collector is still increasing for this area.

Interestingly, the fauna found in the Biological Reserve of Paranapiacaba is more similar to the fauna of Paraná, sharing $31.71 \%$ of the species, while only $8 \%$ of Paranapiacaba species were also observed in Rio Grande do Sul and in Paraná. However, none of those shared species occurs either in the Coastal Plain of RS or in the Sulrio-grandense Shield. And ten species (24.4\%) occur in all these locations and have a wide distribution in Brazil.

The seasonal pattern of Muscidae showed the family individuals more abundant on summer, based on Kruskal-Wallis statistical test (Table 4) and circular analysis (Fig. 5). Previous studies have demonstrated that tropical insect abundance decreases in the dry season (e.g., Pinheiro et al., 2002; Da Silva et al., 2011), but far less than in temperate zones (Wolda, 1988). The pairwise test comparing summer and spring resulted in a statistically relevant difference, but after Bonferroni Correction, this difference was not considered statistically significant (Table 4). On the other hand, Bonferroni tests confirmed seasonal pattern of Muscidae with high abundance in the summer and less in autumn and winter.

Da Silva et al. (2011) and Pinheiro et al. (2002) performed seasonal analyses for insect abundance in the Brazilian Cerrado (savannah) and found that most insect orders (Coleoptera, Hymenoptera, Hemiptera, Isoptera, etc.) showed a clustered distribution, being more abundant in the wet season. However, in both studies, the order Diptera was randomly distributed, contrary to the results observed here and focused on Muscidae. This could be related to the groups studied in each case, revealing perhaps the most abundant groups of Diptera might be equally distributed the whole year, while Muscidae might be more vulnerable to environmental and/or biotic conditions that affect their abundance. Moreover, these studies were performed in different biomes other than Atlantic Forest. Traditionally, Cerrado is characterized by a bimodal rainfall distribution, with two well-defined, dry and wet, seasons (Silva et al., 2008), whereas Atlantic Forest is characterized by having high temperature and precipitation during the whole year (IBGE, 1992). However, climatic studies in Paranapiacaba have demonstrated that precipitation suffers a decrease in December and January (Gutjahr \& Tavares, 2009), when Muscidae reached its peaks in both abundance and diversity. Unfortunately, there are just a few studies with seasonality of Neotropical muscids. Using fruit-baited traps, Azevedo et al. (2015) found the muscids much less abundant in the rainy season in Barbalha municipality (State of Ceará, northeastern Brazil), characterized by Cerrado (savannah) and Caatinga (semi-arid) vegetations. Results of Costacurta et al. (2003) in three localities of State of Paraná (southern Brazil) also supports the correlation between Muscidae abundance and air humidity: the lower the humidity, the higher the abundance. However, as pointed out by Azevedo \& Krüger (2013) for southern Brazilian calliphorids, each species may respond differently (even inversely) to temperature and humidity interactions, therefore, it demands a careful examination on the species other than all the family.

The Paranapiacaba Reserve is covered by secondary Atlantic Forest under different successional stages (Sugiyama et al., 2009). The composition of the Muscidae fauna from the Paranapiacaba Reserve comprises mostly tipically forest species, however there is a number of species with some degree of synanthropic habits. Within its 39 species, only two species, Myospila meditabunda (Fabricius, 1781) and Synthesiomyia nudiseta (Wulp, 1883), are considered tipically synanthropic (Carvalho et al., 2005; Lowenberg-Neto \& Carvalho, 2013). In Colombia, S. nudiseta was classified as having "strong preference for dense human settlements"(Uribe et al., 2010), and in Brazil we have it recorded in rural and urban environments and forest fragments (D'Almeida \& Almeida, 1998). Besides, seven species found in Paranapiacaba have some association to human inhabited areas in Brazil: Cyrtoneuropsis maculipennis, C. polystigma, Morellia humeralis (Stein, 1919), Mydaea plaumanni Snyder, 1941, Phaonia trispila (Bigot, 1885), Pseudoptilolepis fulvapoda Snyder, 1949 and Psilochaeta pampiana (Shannon \& Del Ponte, 1926) (Linhares, 1981; Carvalho et al., 1984; Oliveira, 1986; Kasai et al., 1990; Lomônaco \& Almeida, 1995; Moura et al., 1997; Pamplona et al., 2000; Carvalho et al., 2002; Barbosa et al., 2009). And Cyrtoneuropsis polystigma was also considered symbovine (Oliveira, 1986). However, some species have contrasting information, for example, in Colombia (Uribe et al., 2010), C. maculipennis is classified as a species with "complete avoidance of human settlements", as well as Polietina orbitalis (Stein, 1904).

The occurrence of exotic and/or synanthropic species in natural preserved areas has been associated to edge effect by some authors (Lima-Ribeiro, 2008; Ferraz et al., 2010; Barbosa et al., 2014). Furthermore, the complex composition of the Muscidae fauna in the Biological Reserve of Paranapiacaba reveals that while this Reserve still bears most of its fauna with typically forest species, the presence of some typically synanthropic species may signalize that its proximity to São Paulo metropolitan area has imposed an increasing anthropic pressure (Leandro \& D'Almeida, 2005).

\section{ACKNOWLEDGMENTS}

We thank Filipe Gudin for helping with the material sorting; Filipe Gudin, Julia Calhau, Marcos Ribeiro, Mayra 
Sato, Nelly Araya, Rodrigo Dios and Pedro Souza-Dias for helping in the collecting, and Julia Benetti, Glauco Machado and Daniel Caetano for suggestions on earlier versions. We also thank the financial support from FAPESP with research grant (Proc. № 2007/50836-7 for SSN) and scholarships (Proc. № 2007/52314-7 for ATT and 2010/07185-8 for PM) and CNPq research grant (Proc. № 562199/2010-1 for SSN), scholarship (Proc. № 107159/2011-2 for ATT) and fellowship (Proc. № 309192/2018-8 for SSN).

\section{AUTHORS' CONTRIBUTIONS}

Silvio S. Nihei: Conceptualization, Data curation, Investigation, Methodology, Investigation, Project administration, Resources, Supervision, Validation, Visualization, Writing - original draft, and Writing - review \& editing. Anderson T. Tamakoshi: Data curation, Formal analysis, Investigation, Methodology, Software, and Writing - original draft. Priscylla Moll: Data curation, Formal analysis, Investigation, Methodology, Software, and Writing - original draft. All the authors actively participated in the discussion of the results, they reviewed and approved the final version of the paper. Rodrigo $\mathbf{F}$. Krüger: Methodology, Software, and Writing - original draft and Writing - review \& editing.

\section{CONFLICTS OF INTEREST}

The authors declare that they have no conflict of interest related to the publication of this manuscript.

\section{REFERENCES}

Azevedo, F.R.; Azevedo, R.; Dos Santos, C.A.M.; Moura, E.S. \& Nere, D.R. 2015. Análise Faunística e Flutuação Populacional da Dipterofauna de Ecossistemas da Área de Proteção Ambiental do Araripe, Barbalha, CE. EntomoBrasilis, 8: 117-124. DOI

Azevedo, R.R. \& Krüger, R.F. 2013. The influence of temperature and humidity on abundance and richness of Calliphoridae (Diptera). Iheringia. Série Zoologia, 103(2): 145-152. DOI

Barbosa, L.S.; Cunha, A.M.; Couri, M.S. \& Maia, V.C. 2014. Muscidae, Sarcophagidae, Calliphoridae e Mesembrinellidae (Diptera) da Estação Biológica de Santa Lúcia (Santa Teresa, Espírito Santo, Brasil). Boletim do Museu Biológico Mello Leitão, 33: 131-140.

Barbosa, R.R.; Mello-Patiu, C.A.; Mello, R.P. \& Queiroz, M.M.C. 2009. New records of calyptrate dipterans (Fanniidae, Muscidae and Sarcophagidae) associated with the decomposition of domestic pigs in Brazil. Memórias do Instituto Oswaldo Cruz, 104(6): 923-926. DOI

Borkent, A.; Brown, B.; Adler, P.H.; Amorim, D.S.; Barber, K.; Bickel, D.; Boucher, S.; Brooks, S.E.; Burger, J., Burington, Z.L.; Capellari, R.S.; Costa, D.N.R.; Cumming, J.M.; Curler, G.; Dick, C.W.; Epler, J.H.; Fisher, E.; Gaimari, S.D.; Gelhaus, J.; Grimaldi, D.A.; Hash, J.; Hauser, M.; Hippa, H.; Ibanez-Bernal, S.; Jaschhof, M.; Kameneva, E.P.; Kerr, P.H.; Korneyev, V.; Korytkowski, C.A.; Kung, G.-A.; Kvifte, G.M.; Lonsdale, 0.; Marshall, S.A.; Mathis, W.N.; Michelsen, V.; Naglis, S.; Norrbom, A.L.; Paiero, S.; Pape, T.; PereiraColavite, A.; Pollet, M.; Rochefort, S.; Rung, A.; Runyon, J.B.; Savage, J.;
Silva, V.C.; Sinclair, B.J.; Skevington, J.H.; Stireman, J.0.; Vilkamaa, P.; Wheeler, T.; Whitworth, T.; Wong, M.; Wood, D.M.; Woodley, N.; Yau, T; Zavortink, T.J. \& Zumbado, M.A. 2018. Remarkable fly (Diptera) diversity in a patch of Costa Rican cloud forest: Why inventory is a vital science. Zootaxa, 4402: 53-90. DOI

Brown, B.V. 2005. Malaise trap catches and the crisis in neotropical Dipterology. American Entomologist, 51(3): 180-183. D01

Campos, W.G.; Pereira, D.B.S. \& Schoereder, J.H. 2000. Comparison of the efficiency of flight-interception trap models for sampling hymenoptera and other insects. Anais da Sociedade Entomológica do Brasil, 29(3): 381-389. DOI

Carvalho, C.J.B. De. (Ed.). 2002. Muscidae (Diptera) of the Neotropical Region: Taxonomy. Editora Universidade Federal do Paraná, Curitiba, 287p.

Carvalho, C.J.B. De \& Couri, M.S. 1991. Muscidae, Fanniidae e Calliphoridae (Diptera) do Projeto Maracá, Roraima, Brasil. Acta Amazonica, 21: 35-43. DOI

Carvalho, C.J.B. De; Almeida, J.R. \& Jesus, C.B. 1984. Dípteros sinantrópicos de Curitiba e arredores (Paraná, Brasil). I: Muscidae. Revista Brasileira de Entomologia, 28(4): 551-560.

Carvalho, C.J.B. De; Couri, M.S.; Pont, A.C.; Pamplona, D. \& Lopes, S.M. 2005. A Catalogue of the Muscidae (Diptera) of the Neotropical Region. Zootaxa, 860: 1-282. DOI

Carvalho, C.J.B. De; Moura, M.0. \& Ribeiro, P.B. 2002. Chave para adultos de dípteros (Muscidae, Fanniidae, Anthomyiidae) associados ao ambiente humano no Brasil. Revista Brasileira de Entomologia, 46(2): 107-144. D01

Carvalho, C.J.B. De; Rafael, J.A.; Couri, M.S. \& Silva, V.C. 2012. Diptera. In: Rafael, J.A.; Melo, G.A.R.; Carvalho, C.J.B. de; Casari, S. \& Constantino, R. (Eds.). Insetos do Brasil: diversidade e taxonomia. Ribeirão Preto, Holos Editora. p. 701-743.

Carvalho, R.P.; Azevedo, W.T.A.; Figueiredo, A.L.; Lessa, C.S.S. \& Aguiar, V.M. 2017. Dipterofauna associated with rat carcasses in the Atlantic Forest, Southeastern Brazil. Journal of Medical Entomology, 54(6): 1498-1509. DOI

Cavallari, M.L.; Baltazar, F.N.; Nihei, S.S.; Muñoz, D.R. \& Tolezano, J.E. 2015. Dipterofauna associated with Sus scrofa Linné, 1758, carcasses in urban and coastal regions of São Paulo State, Brazil. Psyche: A Journal of Entomology, article ID 983980, 12p. D0I

Chao, A.; Gotelli, N.J.; Hsieh, T.C.; Sander, E.L.; Ma, K.H.; Colwell, R.K. \& Ellison, A.M. 2014. Rarefaction and extrapolation with Hill numbers: a framework for sampling and estimation in species diversity studies. Ecological Monographs, 84: 45-67. D0I

Colwell, R.K.; Chao, A.; Gotelli, N.J.; Lin, S.-Y.; Mao, C.X.; Chazdon, R.L. \& Longino, J.T. 2012. Models and estimators linking individual-based and sample-based rarefaction, extrapolation and comparison of assemblages. Journal of Plant Ecology, 5: 3-21. DOI

Costacurta, N.C.; Marinoni, R.C. \& Carvalho, C.J.B. De. 2003. Fauna de Muscidae (Diptera) em três localidades do Estado do Paraná, Brasil, capturada por armadilha Malaise. Revista Brasileira de Entomologia, 47(3): 389-397. DOI

Couri, M.S. 1999. Myiasis caused by obligatory parasites. la. Philornis Meinert (Muscidae). In: Guimarães, J.H. \& Papavero, N. (Eds.). Myiasis in man and animals in the Neotropical region. São Paulo, Editora Plêiade. p. 44-70.

Couri, M.S. \& Barros, G.D.S. 2009. Muscidae (Diptera) of Rio de Janeiro State (Southeastern Brazil): inventory of species and notes on biology and distribution. Arquivos do Museu Nacional, 67(3-4): 189-206.

Couri, M.S. \& Carvalho, C.J.B. De. 2005. Diptera Muscidae do Estado do Rio de Janeiro (Brasil). Biota Neotropica, 5: 1-18. D0I

Couri, M.S.; Lamas, C.J.E.; De Cima Aires, C.C.; De Mello-Patiu, C.A.; Maia, V.C.; Pamplona, D.M. \& Magno, P. 2000. Diptera da Serra do Navio (Amapá, Brasil): Asilidae, Bombyliidae, Calliphoridae, Micropezidae, Muscidae, 
Sarcophagidae, Stratiomyiidae, Syrphidae, Tabanidae e Tachinidae. Revista Brasileira de Zoociências, 2(1): 91-101.

D’Almeida, J.M. 1991. Dípteros caliptrados (Muscidae e Anthomyiidae) da região metropolitana do Rio de Janeiro, RJ: II. Atratividade e freqüência sazonal. Revista Brasileira de Zoologia, 8: 7-16. D0I

D'Almeida, J.M. \& Almeida, J.D. 1998. Nichos tróficos em dípteros caliptrados, no Rio de Janeiro, RJ. Revista Brasileira de Biologia, 58(4): 563-570. D0I

Da Silva, N.P.P.; Frizzas, M.R. \& De Oliveira, C.M. 2011. Seasonality in insect abundance in the "Cerrado" of Goiás State, Brazil. Revista Brasileira de Entomologia, 55: 79-87. DOI

Dias, L.S.; Gabriel-Filho, L.R.A. \& Guimarães, R.B. 2014. Avaliação do impacto do programa de coleta seletiva de lixo na frequência de Calliphoridae e Muscidae em Tupã, SP. Sociedade \& Natureza, 26(1): 127-137. Available: http://www.seer.ufu.br/index.php/sociedadenatureza/article/ view/22762.

Dutra, R.R. \& Marinoni, R.C. 1994. Insetos capturados com armadilha Malaise na llha do Mel, Baía de Paranaguá, Paraná, Brasil. I Composição de Ordens. Revista Brasileira de Zoologia, 11(2): 227-245. DOI

Ferraz, A.C.P.; Gadelha, B.Q. \& Aguiar-Coelho, V.M. 2009. Análise faunística de Calliphoridae (Diptera) da Reserva Biológica do Tinguá, Nova Iguaçu, Rio de Janeiro. Revista Brasileira de Entomologia, 53(4): 620-628. D0I

Ferraz, A.C.P.; Gadelha, B.Q. \& Aguiar-Coelho, V.M. 2010. Effects of forest fragmentation on dipterofauna (Calliphoridae) at the Reserva Biológica do Tinguá, Nova Iguaçu, RJ. Brazilian Journal of Biology, 70: 55-63. D0I

Fogaça, J.M. \& Carvalho, C.J.B. de. 2018. Neotropical Lispe (Diptera: Muscidae): notes, redescriptions and key to species. Journal of Natural History, 52(33-34): 2147-2184. D0I

Garcia, F.R.M.; Campos, J.V. \& Corseuil, E. 2003. Análise Faunística de Espécies de Moscas-das-Frutas (Diptera: Tephritidae) na Região Oeste de Santa Catarina. Neotropical Entomology, 32(3): 421-426. DOI

Gutjahr, M.R. \& Tavares, R. 2009. Clima. In: Lopes, M.I.M.S.; Kirizawa, M. \& Mello, M.M.R.F. (Eds.). Patrimômio da Reserva Biológica Alto da Serra de Paranapiacaba. São Paulo, Instituto de Botânica. p. 41-51.

Hammer, 0.; Harper, D.A.T. \& Ryan, P.D. 2001. PAST: Paleontological statistics software package for education and data analysis. Palaeontologia Electronica, 4: 9p. Available: http://palaeo-electronica.org/2001 1/ past/issue1 01.htm. Access: 15/05/2013.

Haseyama, K.L.; Wiegmann, B.M.; Almeida, E.A. \& Carvalho, C.J.B. De. 2015. Say goodbye to tribes in the new house fly classification: a new molecular phylogenetic analysis and an updated biogeographical narrative for the Muscidae (Diptera). Molecular Phylogenetics and Evolution, 89: 1-12. D0I

Hsieh, T.C.; Ma, K.H. \& Chao, A. 2016. iNEXT: An R package for rarefaction and extrapolation of species diversity (Hill numbers). Methods in Ecology and Evolution, 7(12): 1451-1456. DOI

Huckett, H.C. \& Vockeroth, J.R. 1987. Muscidae. In: McAlpine, J.F.; Peterson, B.V.; Shewell, G.H.; Teskey, H.J.; Vocheroth, J.R. \& Wood, D.M. (Eds.). Manual of Neartic Diptera. Ottawa, Agriculture Canada. v. 2, p. 1115-1131.

Instituto Brasileiro de Geografia e Estatística (IBGE). 1992. Manual técnico da vegetação brasileira. Rio de Janeiro, IBGE. 92p.

Kasai, N.; Schumaker, T.T.S.; Dell'Porto, A. \& La Salvia, V. 1990. Variação sazonal de dípteros capturados em armadilhas de Magoon modificada, em Santana do Parnaíba, Estado de São Paulo. Revista Brasileira de Entomologia, 34(2): 369-380.

Krüger, R.F.; Carvalho, C.J.B. De \& Ribeiro, P.B. 2010. Assembly rules in Muscid fly assemblages in the grasslands biome of Southern Brazil. Neotropical Entomology, 39(3): 345-353. DOI

Leandro, M.J. \& D'Almeida, J.M. 2005. Levantamento de Calliphoridae, Fanniidae, Muscidae e Sarcophagidae em um fragmento de mata na Ilha do Governador, Rio de Janeiro, Brasil. Iheringia. Série Zoologia, 95(4): 377-381. D01
Lima-Ribeiro, M.S. 2008. Efeitos de borda sobre a vegetação e estruturação populacional em fragmentos de Cerradão no Sudoeste Goiano, Brasil. Acta Botanica Brasilica, 22(2): 535-545. D01

Linhares, A.X. 1981. Synanthropy of Muscidae, Fanniidae and Anthomyiidae (Diptera) in the city of Campinas, São Paulo, Brazil. Revista Brasileira de Entomologia, 25(4): 231-243.

Lomônaco, C. \& Almeida J.R. 1995. Sazonalidade e uso de recursos para alimentação e oviposição de dípteros muscóideos na restinga de Jacarepaguá, Rio de Janeiro, Brasil. Revista Brasileira de Entomologia, 39(4): 883-890.

Lowenberg-Neto, P. \& Carvalho, C.J.B. De. 2013. Muscidae (Insecta: Diptera) of Latin America and the Caribbean: geographic distribution and check-list by country. Zootaxa, 3650: 1-147. DOI

Magurran, A.E. 1988. Ecological diversity and Its measurement. Princeton, Princeton University Press, 179p. DOl

Moura, M.0.; Carvalho, C.J.B. De \& Monteiro-Filho, E.L. 1997. A preliminary analysis of insects of medico-legal importance in Curitiba, State of Paraná. Memórias do Instituto Oswaldo Cruz, 92(2): 269-274. D0I

Mulieri, P.R.; Patitucci, L.D.; Schnack, J.A. \& Mariluis, J.C. 2011. Diversity and seasonal dynamics of an assemblage of sarcophagid Diptera in a gradient of urbanization. Journal of Insect Science, 11: 1-15. DOI

Nakagawa, S. 2004. A farewell to Bonferroni: the problems of low statistical power and publication bias. Behavioral Ecology, 15(6): 1044-1045. D01

Nihei, S.S. \& Carvalho, C.J.B. DE. 2007. Phylogeny and classification of Muscini (Diptera, Muscidae). Zoological Journal of the Linnean Society, 149(4): 493-532. DOI

Olea, M.S.; Patitucci, L.D.; Mariluis, J.C.; Alderete, M. \& Mulieri, P.R. 2017. Assessment of sampling methods for sarcosaprophagous species and other guilds of Calyptratae (Diptera) in temperate forests of Southern South America. Journal of Medical Entomology, 54(2): 349-361. D0I

Oliveira, G.P. 1986. Distribuição sazonal de dípteros muscóides sinantrópicos, simbovinos e foréticos de Dermatobia hominis L. Jr. em São Carlos, Estado de São Paulo. I. Estábulo. Arquivo de Biologia e Tecnologia, 29(2): 311-325.

Oliveira, V.D.; D'Almeida, J.M.; Paes, M.J. \& Sanavria, A. 2002. Population dynamics of calyptrate Diptera (Muscidae and Sarcophagidae) at the Rio-Zoo foundation, Rio de Janeiro, RJ, Brazil. Brazilian Journal of Biology, 62(2): 191-196. D01

Pamplona, D.; Maia, V.C.; Couri, M.S.; Lamas, C.J.E. \& Aires, C.D.C. 2000. A survey of Diptera on Paquetá Island, Rio de Janeiro, Brazil. Entomologist's Monthly Magazine, 136(1632-1635): 169-175.

Pape, T.; Blagoderov, V. \& Mostovski, M.B. 2011. Order Diptera Linnaeus, 1758. In: Zhang, Z.-Q. (Ed.). Animal biodiversity: an outline of higherlevel classification and survey of taxonomic richness. Zootaxa, 3148: 1-237. DOI

Pereira-Colavite, A. \& Carvalho, C.J.B. De. 2012. Taxonomy of Neomuscina Townsend (Diptera, Muscidae) from Brazil. Zootaxa, 3504: 1-55. D0I

Pinheiro, F.; Diniz, I.R.; Coelho, D. \& Bandeira, M.P.S. 2002. Seasonal pattern of insect abundance in the Brazilian cerrado. Austral Ecology, 27(2): 132-136. D0I

Rodrigues, W.C. 2005. DivEs - Diversidade de espécies. Versão 2.0. Available: http://www.ebras.bio.br/dives. Access: 21/05/2013.

Rodríguez-Fernández, J.I.; Carvalho, C.J.B. De \& Moura, M.0. 2006. Estrutura de assembléias de Muscidae (Diptera) no Paraná: uma análise por modelos nulos. Revista Brasileira de Entomologia, 50: 93-100. DOI

Savage, J. \& Vockeroth, J.R. 2010. Family Muscidae. In: Brown, B.V.; Borkent, A.; Cumming, J.M.; Wood, D.M.; Woodley, N.E. \& Zumbado, M.A. (Eds.). Manual of Central American Diptera. Ottawa, NRC Research Press. v. 2, p. $1281-1295$ 
Silva, F.A.M.; Assad, E.A. \& Evangelista, B.A. 2008. Caracterização climática do bioma Cerrado. In: Sano, S.M.; Almeida, S.P. \& Ribeiro, J.F. (Eds.). Cerrado: ecologia e flora. Brasília, EMBRAPA Informação Tecnológica. p. 69-88.

Sugiyama, M.; Dos Santos, R.P.; Aguiar, L.S.J.; Kirizawa, M. \& Catharino, E.L.M. 2009. Caracterização e Mapeamento da Vegetação. In: Lopes, M.I.M.S.; Kirizawa, M. \& Mello, M.M.R.F. (Eds.). Patrimômio da Reserva Biológica Alto da Serra de Paranapiacaba. São Paulo, Instituto de Botânica. p. 41-51.

Townsend, C.H.T. 1927. Synopse dos gêneros muscoideos da região humida tropical da America, com gêneros e espécies novas. Revista do Museu Paulista, 15: 203-385.
Uribe, N.; Wolff, M. \& De Carvalho, C.J.B. De. 2010. Synanthropy and ecological aspects of Muscidae (Diptera) in a tropical dry forest ecosystem in Colombia. Revista Brasileira de Entomologia, 54(3): 462-470. D01

Wolda, H. 1988. Insect seasonality: Why? Annual Review of Ecology, Evolution and Systematics, 19: 1-18. DOI

Zafalon-Silva, A.; Kirst, F.D. \& Krüger, R.F. 2018. Houseflies speaking for the conservation of natural areas: a broad sampling of Muscidae (Diptera) on coastal plains of the Pampa biome, Southern Brazil. Revista Brasileira de Entomologia, 64(4): 292-303. D01

\section{APPENDIX: LIST OF EXAMINED MATERIAL}

The species are listed in alphabetical order. Asterisk indicates new records to State of São Paulo. All material deposited at the Museu de Zoologia, Universidade de São Paulo, Brazil (MZSP).

Cyrtoneurina alifusca Couri, 1982: 1 male, 21.x-19.xi.2010, Gudin \& Nihei col.; 1 male, 19.xi-21.xii.2010, Gudin, Araya \& Nihei col.; 3 males, 21.xii.2010-21.i.2011, Sato \& Nihei col.; 2 males, 21.i-22.ii.2011, Gudin \& Dios col.

Cyrtoneurina costalis (Walker, 1853): 1 male, 22.iii-19.iv.2011, Moll \& Nihei col.

Cyrtoneuropsis maculipennis Macquart, 1843: 1 female, 21.vii-21.viii.2010, Moll \& Nihei col.; 2 males, 1 female, 21.viii-21.ix.2010, Gudin \& Nihei col.; 3 females, 21.ix-21.x.2010, Dios \& Nihei col.; 1 male, 4 females, 21.x-19.xi.2010, Gudin \& Nihei col.; 1 male, 13 females, 19.xi-21.xii.2010, Gudin, Araya \& Nihei col.; 1 male, 8 females, 21.xii.2010-21.i.2011, Sato \& Nihei col.; 3 males, 13 females, 21.i-22.ii.2011, Gudin \& Dios col.; 6 females, 23.ii-21.iii.2011, Moll, Nihei \& Dias col.; 1 male, 3 females, 22.iii-19.iv.2011, Moll \& Nihei col.; 2 males, 6 females, 19.iv-23.v.2011, Moll \& Gudin col.; 3 females, 23.v-20.vi.2011, Moll, Almeida \& Tamakoshi col.; 2 males, 1 female, 20.vi-23.vii.2011, Moll, Tamakoshi, Ribeiro col.

Cyrtoneuropsis polystigma (Wulp, 1896): 1 female, 21.vii-21.viii.2010, Moll \& Nihei col.; 2 males, 21.viii-21.ix.2010, Gudin \& Nihei col.; 4 males, 2 females, 21.ix-21.x.2010, Dios \& Nihei col.; 2 males, 4 females, 21.x-19.xi.2010, Gudin \& Nihei col.; 5 males, 4 females, 19.xi-21.xii.2010, Gudin, Araya \& Nihei col.; 4 males, 1 female, 21.xii.2010-21.i.2011, Sato \& Nihei col.; 3 males, 4 females, 21.i-22.ii.2011, Gudin \& Dios col.

Dolichophaonia machadoi (Albuquerque, 1958)*: 4 females, 21.vii-21.viii.2010, Moll \& Nihei col.; 2 females, 21.viii-21.ix.2010, Gudin \& Nihei col.; 4 females, 21.x-19.xi.2010, Gudin \& Nihei col.; 2 females, 19.xi-21.xii.2010, Gudin, Araya \& Nihei col.; 1 female, 21.i-22.ii.2011, Gudin \& Dios col.; 1 female, 19.iv-23.v.2011, Moll \& Gudin col.; 1 female, 20.vi-23.vii.2011, Moll, Tamakoshi, Ribeiro col.

Dolichophaonia simplex (Albuquerque, 1958)*: 1 female, 21.viii-21.ix.2010, Gudin \& Nihei col.

Helina aff. discreta (Wulp, 1896)*: 3 females, 21.xii.2010-21.i.2011, Sato \& Nihei col.; 1 female, 23.ii-21.iii.2011, Moll, Nihei \& Dias col.

Helina gigantea Albuquerque, 1956*: 2 females, 21.x-19.xi.2010, Gudin \& Nihei col.

Helina praecipua (Walker, 1853): 1 male, 23.v-20.vi.2011, Moll, Almeida \& Tamakoshi col.

Helina regobarrosi Albuquerque, 1958*: 1 male, 19.xi-21.xii.2010, Gudin, Araya \& Nihei col.; 1 female, 21.xii.2010-21.i.2011, Sato \& Nihei col.; 1 female, $21 . i-22$. ii.2011, Gudin \& Dios col.

Morellia humeralis (Stein, 1919): 1 female, 21.i-22.ii.2011, Gudin \& Dios col.

Morellia nigricosta Hough, 1900: 3 females, 21.i-22.ii.2011, Gudin \& Dios col.

Mydaea plaumanni Snyder, 1941: 1 female, 21.ix-21.x.2010, Dios \& Nihei col.; 3 females, 21.xii.2010-21.i.2011, Sato \& Nihei col.; 1 female, 19.iv-23.v.2011, Moll \& Gudin col.; 1 female, 23.v-20.vi.2011, Moll, Almeida \& Tamakoshi col.; 2 females, 20.vi-23.vii.2011, Moll, Tamakoshi, Ribeiro col.

Myospila meditabunda (Fabricius, 1781): 1 female, 21.x-19.xi.2010, Gudin \& Nihei col.; 1 female, 19.xi-21.xii.2010, Gudin, Araya \& Nihei col.

Neomuscina anajeensis Pereira-Colavite \& Carvalho 2012*: 1 female, 21.x-19.xi.2010, Gudin \& Nihei col.

Neomuscina atincticosta Snyder, 1949: 1 male, 21.xii.2010-21.i.2011, Sato \& Nihei col. 
Neomuscina inflexa (Stein, 1918): 2 females, 21.xii.2010-21.i.2011, Sato \& Nihei col.

Neomuscina neosimilis Snyer, 1949: 1 female, 19.xi-21.xii.2010, Gudin, Araya \& Nihei col.; 1 female, 21.xii.2010-21.i.2011, Sato \& Nihei col.

Neomuscina schadei Snyder, 1949: 1 female, 23.ii-21.iii.2011, Moll, Nihei \& Dias col.

Neomuscina transporta Snyder, 1949*: 1 female, 21.x-19.xi.2010, Gudin \& Nihei col.

Neurotrixa sulina Costacurta \& Carvalho, 2005*: 1 female, 19.xi-21.xii.2010, Gudin, Araya \& Nihei col.

Phaonia advena Snyder, 1957*: 2 females, 21.vii-21.viii.2010, Moll \& Nihei col.; 2 males, 7 females, 21.viii-21.ix.2010, Gudin \& Nihei col.; 3 females, 21.ix-21.x.2010, Dios \& Nihei col.; 1 male, 5 females, 21.x-19.xi.2010, Gudin \& Nihei col.; 1 male, 13 females, 19.xi-21.xii.2010, Gudin, Araya \& Nihei col.; 5 females, 21.xii.2010-21.i.2011, Sato \& Nihei col.; 1 male, 21.i-22.ii.2011, Gudin \& Dios col.; 4 females, 23.ii-21.iii.2011, Moll, Nihei \& Dias col.; 2 females, 22.iii-19.iv.2011, Moll \& Nihei col.; 6 females, 19.iv-23.v.2011, Moll \& Gudin col.; 1 female, 23.v-20.vi.2011, Moll, Almeida \& Tamakoshi col.; 2 females, 20.vi-23.vii.2011, Moll, Tamakoshi, Ribeiro col.

Phaonia annulata (Albuquerque, 1957)*: 1 female, 21.xii.2010-21.i.2011, Sato \& Nihei col.; 1 male, 19.iv-23.v.2011, Moll \& Gudin col.

Phaonia grajauensis (Albuquerque, 1957): 2 female, 21.xii.2010-21.i.2011, Sato \& Nihei col.

Phaonia grandis (Couri, 1982)*: 1 male, 12 females, 21.vii-21.viii.2010, Moll \& Nihei col.; 3 males, 9 females, 21.viii-21.ix.2010, Gudin \& Nihei col.; 1 male, 6 females, 21.ix-21.x.2010, Dios \& Nihei col.; 5 females, 21.x-19.xi.2010, Gudin \& Nihei col.; 11 females, 19.xi-21.xii.2010, Gudin, Araya \& Nihei col.; 1 male, 4 females, 21.xii.2010-21.i.2011, Sato \& Nihei col.; 3 males, 13 females, 21.i-22.ii.2011, Gudin \& Dios col.; 1 male, 5 females, 23.ii-21.iii.2011, Moll, Nihei \& Dias col.; 2 male, 5 females, 22.iii-19.iv.2011, Moll \& Nihei col.; 1 male, 11 females, 19.iv-23.v.2011, Moll \& Gudin col.; 8 females, 23.v-20.vi.2011, Moll, Almeida \& Tamakoshi col.; 2 males, 6 females, 20.vi-23.vii.2011, Moll, Tamakoshi, Ribeiro col.

Phaonia lentiginosa Snyder 1957*: 2 males, 21.vii-21.viii.2010, Moll \& Nihei col.; 1 female, 21.viii-21.ix.2010, Gudin \& Nihei col.; 1 female, 21.ix-21.x.2010, Dios \& Nihei col.; 3 females, 21.x-19.xi.2010, Gudin \& Nihei col.; 1 male, 5 females, 21.xii.2010-21.i.2011, Sato \& Nihei col.; 1 female, 21.i-22.ii.2011, Gudin \& Dios col.; 1 female, 22.iii-19.iv.2011, Moll \& Nihei col.; 2 females, 19.iv-23.v.2011, Moll \& Gudin col.

Phaonia shannoni (Carvalho \& Pont, 1993): 1 female, 21.vii-21.viii.2010, Moll \& Nihei col.; 1 female, 21.viii-21.ix.2010, Gudin \& Nihei col.; 1 female, 21 .i-22. ii.2011, Gudin \& Dios col.; 1 female, 20.vi-23.vii.2011, Moll, Tamakoshi, Ribeiro col.

Phaonia similata (Albuquerque, 1957): 1 female, 21.viii-21.ix.2010, Gudin \& Nihei col.

Phaonia trispila (Bigot, 1885): 1 male, 1 female, 23.v-20.vi.2011, Moll, Almeida \& Tamakoshi col.

Philornis amazonenses Couri, 1983: 1 female, 21.viii-21.ix.2010, Gudin \& Nihei col.; 1 female, 21.i-22.ii.2011, Gudin \& Dios col.

Polietina minor (Albuquerque, 1956)*: 1 female, 21.i-22.ii.2011, Gudin \& Dios col.

Polietina orbitalis (Stein, 1904): 1 female, 19.xi-21.xii.2010, Gudin, Araya \& Nihei col.

Polietina prima (Couri \& Machado, 1990): 2 females, 21.xii.2010-21.i.2011, Sato \& Nihei col.; 1 female, 21.i-22.ii.2011, Gudin \& Dios col.; 2 females, $23 . i i-21$. iii.2011, Moll, Nihei \& Dias col.; 1 male, 22.iii-19.iv.2011, Moll \& Nihei col.; 1 female, 19.iv-23.v.2011, Moll \& Gudin col.

Polietina steini (Enderlein, 1927): 2 females, 19.xi-21.xii.2010, Gudin, Araya \& Nihei col.

Polietina univittata Couri \& Carvalho, 1996: 1 female, 19.xi-21.xii.2010, Gudin, Araya \& Nihei col.; 2 females, 21.i-22.ii.2011, Gudin \& Dios col.; 1 female, 23.ii-21.iii.2011, Moll, Nihei \& Dias col.

Pseudoptilolepis fulvapoda Snyder, 1949: 2 females, 21.viii-21.ix.2010, Gudin \& Nihei col.; 3 females, 21.ix-21.x.2010, Dios \& Nihei col.; 1 female, $21 . x-19$. xi.2010, Gudin \& Nihei col.; 1 female, 19.xi-21.xii.2010, Gudin, Araya \& Nihei col.; 1 male, 1 female, 21.xii.2010-21.i.2011, Sato \& Nihei col.; 1 female, 21.i-22.ii.2011, Gudin \& Dios col.; 1 female, 23.ii-21.iii.2011, Moll, Nihei \& Dias col.; 1 female, 20.vi-23.vii.2011, Moll, Tamakoshi, Ribeiro col.

Pseudoptilolepis nudapleura Snyder, 1949: 1 female, 21.xii.2010-21.i.2011, Sato \& Nihei col.

Psilochaeta pampiana (Shannon \& Del Ponte, 1926): 1 male, 19.xi-21.xii.2010, Gudin, Araya \& Nihei col.; 1 male, 21.xii.2010-21.i.2011, Sato \& Nihei col.

Synthesiomyia nudiseta (Wulp, 1883): 1 female, 23.ii-21.iii.2011, Moll, Nihei \& Dias col. 